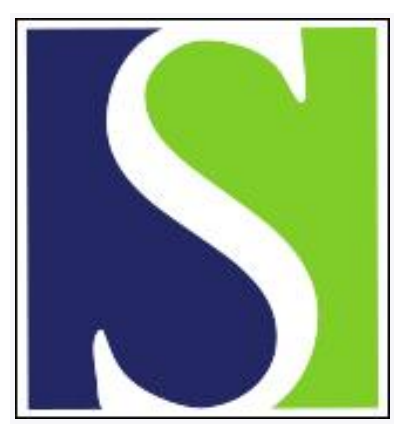

Scand J Work Environ Health 1979;5(3):211-216

https://doi.org/10.5271/sjweh.3095

Issue date: Sep 1979

In vitro cytotoxicity of cadmium microparticles for rabbit pulmonary alveolar macrophages

by Dubreuil A, Bouley G, Boudene C

Affiliation: U. 122 de I' I.N.S.E.R.M., Centre Pharmaceutique de I' Universite Paris-Sud, 92290 Chatenay-Malabry, France.

Refers to the following text of the Journal: 1977;3(3):116-121

Key terms: alveolar macrophage; cadmium; cadmium microparticle; cytotoxicity; in vitro; microparticle; phagocytosis; pulmonary alveolar macrophage; rabbit pulmonary alveolar macrophage

This article in PubMed: www.ncbi.nlm.nih.gov/pubmed/20120569 


\title{
In vitro cytotoxicity of cadmium microparticles for rabbit pulmonary alveolar macrophages
}

\author{
by ALAIN DUBREUIL, M.Sc., GEORGES BOULEY, D.V.M., and \\ CLAUDE BOUDENE, D.Sc. ${ }^{1}$
}

\begin{abstract}
DUBREUIL, A., BOULEY, G. and BOUDENE, C. In vitro cytotoxicity of cadmium microparticles for rabbit pulmonary alveolar macrophages. Scand. j. work environ. \& health 5 (1979) $211-216$. A cytotoxic effect of cadmium monoxide microparticles on rabbit pulmonary alveolar macrophages was observed in vitro from 1 to $2 \mu \mathrm{g}$ of metal cadmium per million cells (and per milliliter of incubation medium). This threshold was close to the one observed with lead microparticles, which in addition appeared to have a faster cytotoxic action. On the other hand, cadmium microparticles inhaled in vivo are known to be much more toxic to the respiratory system and much more slowly cleared from it than lead particles. These contradictions can be partially explained by our observation that in vitro the ability of alveolar macrophages to phagocytize microparticles was significantly lower for cadmium monoxide than for lead monoxide microparticles.
\end{abstract}

Key words: alveolar macrophages, cadmium, cytotoxicity, microparticles, phagocytosis.

Heavy metals are present in the air in increasing amounts (5). Although biological research on the toxic effects of cadmium has mainly concerned soluble forms of this metal, it seems that this heavy metal is present in polluted atmospheres chiefly in the form of cadmium oxide particles (8). After studying rats and mice exposed to cadmium fumes via the respiratory route (4), we have investigated the cytotoxic effect of cadmium monoxide microparticles on rabbit alveolar macrophages in vitro.

1 U. 122 I.N.S.E.R.M. and Toxicology Research
Center, University Paris XI, France.

Reprint requests to: Mr. A. Dubreuil, U. 122 de l' I.N.S.E.R.M., Centre Pharmaceutique de l' Université Paris-Sud, rue J. B. Clément, 92290 Chatenay-Malabry, France.

\section{MATERIAL AND METHODS}

\section{Microparticles}

Microparticle suspensions were produced by the ultrasonication of cadmium monoxide (CdO) powder (for test macrophages) or alumina $\left(\mathrm{Al}_{2} \mathrm{O}_{3}\right)$ powder (for controls) in water. Size selection of particles was performed by gravity so that 72 to $88 \%$ of the CdO particles (95 \% confidence limits at $p=0.05$ ) and 85 to $95 \%$ of the $\mathrm{Al}_{2} \mathrm{O}_{3}$ particles had a diameter equal to or less than $3 \mu \mathrm{m}$ (physical diameter determined from photomicrographies of the particles). Cadmium dosage was performed by means of flameless atomic spectrophotometry at $228.8 \mathrm{~nm}$ after the dissolution of the CdO particles in suprapure 
nitric acid. The $\mathrm{Al}_{2} \mathrm{O}_{3}$ suspensions were adjusted to equal the number of particles in the CdO suspensions.

\section{Macrophages}

We obtained the alveolar macrophages through the pulmonary washing of 22 "Fauves de Bourgogne" male rabbits (mean body weight and standard deviation: $3 \pm 0.5 \mathrm{~kg}$ ) according to a modified version of the procedure of Myrvik et al. (15) using a sterile saline isotonic buffer solution without cadmium or magnesium. The collected free alveolar cells were dispersed in Eagle minimum essential medium (MEM) supplemented with $10 \%$ fetal calf serum (FCS) and antibiotics in order to obtain $1 \times 10^{6}$ viable macrophages per milliliter of medium. For $3 \mathrm{~h}$ at $37^{\circ} \mathrm{C}$ in vitro, the macrophages were allowed to adhere to the glass, and the medium with the nonadherent cells was removed and replaced by fresh MEM with FCS, but without penicillin. The $\mathrm{CdO}$ or $\mathrm{Al}_{2} \mathrm{O}_{3}$ microparticles were then added in various concentrations - expressed in micrograms of metal cadmium per $10^{6}$ macrophages at time 0 or in the equivalent amounts of $\mathrm{Al}_{2} \mathrm{O}_{3}$ in number of particles. $\mathrm{A}$ total of $62 \pm 18 \times 10^{6}$ viable macrophages was collected per rabbit, and these cells were observed between the 5th and 120th hour of exposure.

\section{Tests}

The following quantitative tests were chosen: (a) macrophage death rate measured by the trypan blue exclusion test for cell viability (17); (b) evolution of the cellular lysis percentage (determination of the number of viable and dead cells harvested in vitro in comparison to the initial number of macrophages); (c) $\mathrm{pH}$ evolution of the macrophage culture medium (colorimetric determination) as a function of time; (d) study of protein synthesis by the incorporation of ${ }^{3} \mathrm{H}$-leucine (20); (e) dissolved oxygen consumption, measured by Clark's electrode (12) and expressed in nanomoles per minute and per $10^{6}$ viable cells (Krebs-Ringer medium with glucose and phosphate buffer); (f) ability of the macrophages to phagocytize latex microparticles of $0.8 \mu \mathrm{m}$ after $1 \mathrm{~h}$ of contact at $37^{\circ} \mathrm{C}$ in Leighton's tubes (100 particles per adherent cell); (g) phagocytosis and inactivation of Saccharomyces cerevisiae by the macrophages during $3 \mathrm{~h}$ at $37^{\circ} \mathrm{C}$ in Leighton's tubes (two yeast cells per viable macrophage) - study by microorganism colony counting in agar medium (16); and (h) comparative phagocytosis of $\mathrm{CdO}$ microparticles and of lead monoxide $(\mathrm{PbO})$ microparticles by the rabbit alveolar macrophages in Leighton's tubes (10 particles per cell).

The data were statistically analyzed by the following tests: Pearson's chi-square, Student's t- and paired t-, and Wilcoxon's T-tests (13), according to the number of measurements and to the experimental conditions.

\section{RESULTS}

Only the data indicating significant differences between the control and test cells have been reported.

We studied the viable counts of the macrophages in the following two ways: (a) by plotting the death rate $(\%)$ against the amounts of cadmium or the $\mathrm{Al}_{2} \mathrm{O}_{3}$ equivalents at the 18th hour of exposure (fig. 1) and (b) by plotting the death rate $(0 \%)$ against the time of exposure, between the 5th and the 48th hour, for $6 \mu \mathrm{g}$ of cadmium per $10^{6}$ cells or for the $\mathrm{Al}_{2} \mathrm{O}_{3}$ equivalent (fig. 2). The slopes of the straight lines fitted according to the equation $y=a+b x$ were significantly different for the test and control cells in both cases $(t=14.247, p=0$ and $t=$ 12.232, $\mathrm{p}=0$ ). The threshold dose of cadmium cytotoxicity in vitro was 1 to 2 $\mu \mathrm{g}$ per $10^{6}$ cells (and per milliliter of medium), but this effect of the pollutant appeared slowly (after about $12 \mathrm{~h}$ ).

The $\mathrm{pH}$ values of the culture medium were plotted against the time of exposure (fig. 3), for $6 \mu \mathrm{g}$ of cadmium per $10^{6}$ cells or for the $\mathrm{Al}_{2} \mathrm{O}_{3}$ equivalent, between time 0 and the 120 th hour. The slopes of the straight lines fitted according to the equa- 
tion $\mathrm{y}=\mathrm{a}+\mathrm{bx}$ were significantly different for the test and control cells $(t=$ $2.395, p=0.023$ ), but not for less amounts of cadmium.
Dissolved oxygen consumption was studied at the 20th hour of exposure to $4 \mu \mathrm{g}$ of cadmium or to the $\mathrm{Al}_{2} \mathrm{O}_{3}$ equivalent. The difference between the consumption

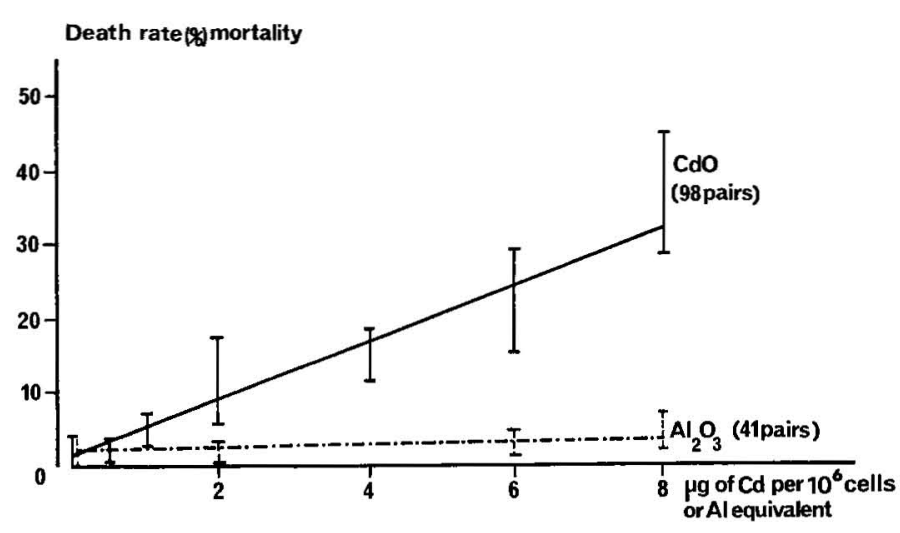

Death rate (\%) mortality
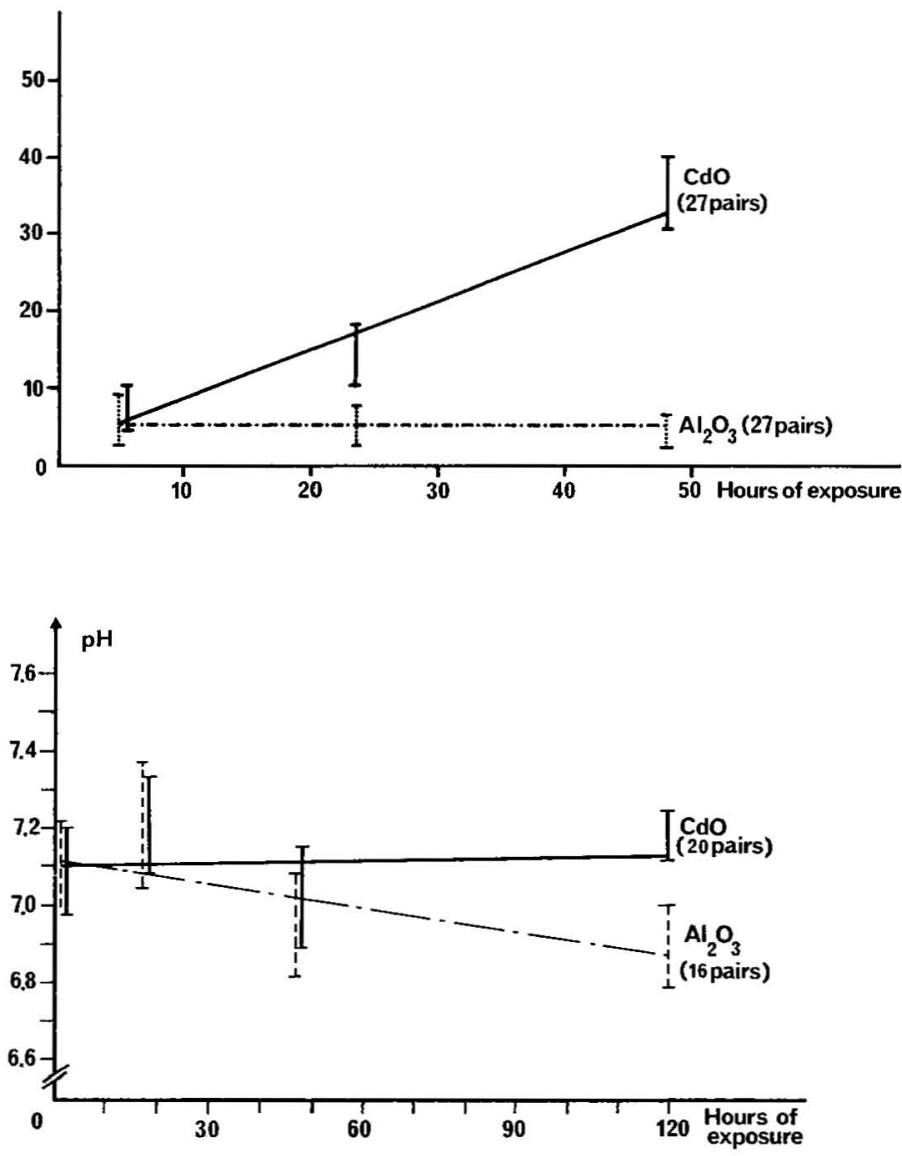

Fig. 1. Death rate of alveolar macrophages at the 18th hour of exposure to different amounts of particulate cadmium or aluminium. (vertical segments: two standard deviations; pairs: paired data $\mathrm{xy}$ )

Fig. 2. Death rate of alveolar macrophages with $6 \mu \mathrm{g}$ of particulate cadmium per $10^{6}$ cells or the alumina equivalent. (abscissa: exposure time; vertical segments: two standard deviations; pairs: paired data $\mathrm{xy}$ )
Fig. 3. Ordinate: $\mathrm{pH}$ of culture medium with $6 \mu \mathrm{g}$ of particulate cadmium per $10^{6}$ cells or the alumina equivalent. (abscissa: exposure time; vertical segments: two standard deviations; pairs: paired data $x y$ ) 
Table 1. Oxygen consumption (nanomolar $\mathrm{O}_{2} / \mathrm{min}$ per $10^{6}$ viable cells) at the 20th hour of exposure to $4 \mu \mathrm{g}$ of particulate cadmium monoxide (CdO) or to the alumina $\left(\mathrm{Al}_{2} \mathrm{O}_{3}\right)$ equivalent.

$\mathrm{Cells}+\mathrm{CdO} \mathrm{Cells}+\mathrm{Al}_{2} \mathrm{O}_{3}$

\begin{tabular}{lcc}
\hline $\begin{array}{l}\text { Number of data } \\
\text { O2 consumption } \\
\text { (mean } \pm 1 \text { SD) }\end{array}$ & $1.938 \pm 0.656$ & $2.827 \pm 0.624$ \\
\hline Statistical analysis & $\mathrm{T}=0$ & $\mathrm{p}=0.01$ \\
\hline
\end{tabular}

of intoxicated and control macrophages was statistically significant (table 1).

Latex particles were added to the cells at the 18th hour of exposure. The percentage of macrophages phagocytizing more than three latex particles was plotted against the amounts of cadmium or the $\mathrm{Al}_{2} \mathrm{O}_{3}$ equivalents (fig. 4). The slopes of the straight lines were not significantly different for the test and control cells, but the percentage of macrophages having phagocytized more than three latex particles became significantly lower in test cells above the level of $2 \mu \mathrm{g}$ of cadmium (controls: $\mathrm{N}=10$, mean $\pm \mathrm{SD}=43 \pm 13$ $\%$; test cells: $\mathrm{N}=10$, mean $\pm \mathrm{SD}=30 \pm$ $13 \% ; \mathrm{t}=2.219, \mathrm{p}=0.039$ ).

The phagocytosis and inactivation of $S$. cerevisiae, added to the macrophages at the 18th hour of exposure to $4 \mu \mathrm{g}$ of cadmium or to the $\mathrm{Al}_{2} \mathrm{O}_{3}$ equivalent per $10^{6}$ viable cells, were expressed in the follow- ing three ways: (a) number of phagocytized yeasts per $100 \mathrm{~S}$. cerevisiae initially introduced into the macrophage culture, (b) number of yeasts inactivated (nonviable) per $100 \mathrm{~S}$. cerevisiae phagocytized, and (c) number of yeasts inactivated per $100 \mathrm{~S}$. cerevisiae initially introduced into the macrophage culture. The differences between the control and test macrophages were statistically significant in all three cases (table 2).

The alveolar macrophage ability to phagocytize $\mathrm{CdO}$ and $\mathrm{PbO}$ microparticles is compared in table 3 ; the phagocytosis of CdO was significantly lower than that of $\mathrm{PbO}$.

\section{DISCUSSION}

The research on the cytotoxic mechanism of cadmium reported in the literature has been conducted using soluble forms of this heavy metal $\left(\mathrm{Cd}^{++}\right)$. Under these conditions the main target cellular organelle is the nucleus $(11,19)$; a modification of nucleolar ultrastructure and RNA synthesis inhibition appear. But mitochondrias are also targets (18); $\mathrm{Cd}^{++}$ impairs the electron transport chain before the cytochrome components and thus inhibits macrophage respiration (6, 14). $\mathrm{Cd}^{++}$impairs the activity of plasma membrane receptors for the Fc portion of antibodies (10) (inhibition of the rosette

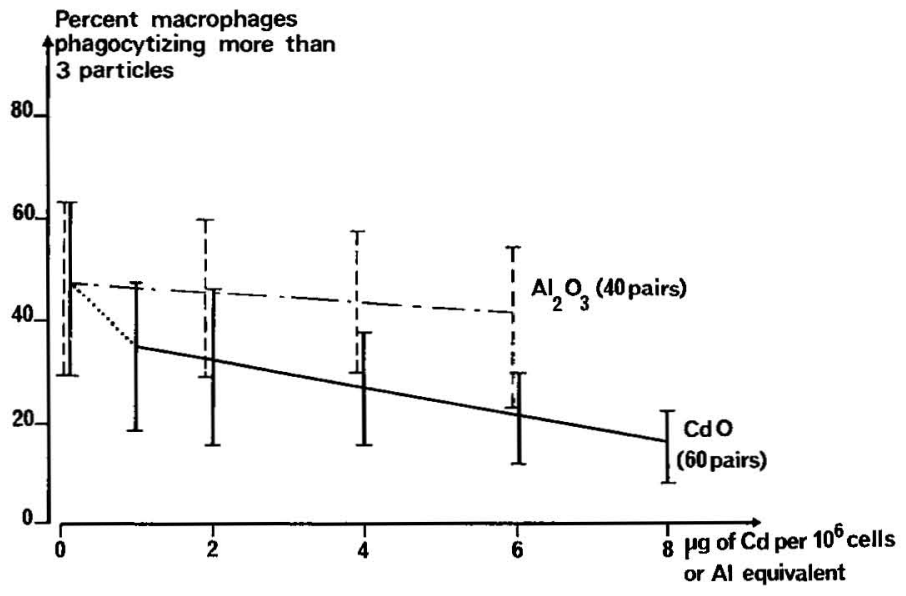

Fig. 4. Alveolar macrophage ability to phagocytize latex microparticles at the 18th hour of exposure to different amounts of particulate cadmium or aluminium. (vertical segments: two standard deviations) 
Table 2. Phagocytic and germicidal activity of macrophages against $S$. cerevisiae at the 18th hour of exposure to $4 \mu \mathrm{g}$ of particulate cadmium monoxide (CdO) or to the alumina $\left(\mathrm{Al}_{2} \mathrm{O}_{3}\right)$ equivalent.

\begin{tabular}{|c|c|c|c|}
\hline & \multirow{2}{*}{$\begin{array}{l}\text { Phagocytized } \\
\text { yeasts }(\%)\end{array}$} & \multirow{2}{*}{$\frac{\text { Killed yeasts }}{\text { Phagocytized yeasts }}(\%)$} & Killed yeasts \\
\hline & & & Total number of yeasts \\
\hline \multicolumn{4}{|l|}{ Macrophages + CdO } \\
\hline Number of data & 7 & 7 & 7 \\
\hline Mean $\pm 1 \mathrm{SD}$ & $16 \pm 9$ & $43 \pm 30$ & $10 \pm 10$ \\
\hline \multicolumn{4}{|l|}{ Macrophages $\pm \mathrm{Al}_{2} \mathrm{O}_{3}$} \\
\hline Number of data & 7 & 7 & 7 \\
\hline Mean \pm 1 SD & $50 \pm 25$ & $81 \pm 7$ & $41 \pm 22$ \\
\hline
\end{tabular}

Significant differences between control and test macrophages: $\mathrm{T}=0 ; \mathrm{p}=0.02$

Table 3. Comparative phagocytosis of cadmium monoxide (CdO) and lead monoxide ( $\mathrm{PbO}$ ) microparticles by rabbit alveolar macrophages.

\begin{tabular}{lccc}
\hline & $\mathrm{CdO}$ & $\mathrm{PbO}$ & $\begin{array}{c}\text { Statistical } \\
\text { analysis }\end{array}$ \\
\hline $\begin{array}{l}\text { 1-h phagocytosis } \\
\text { Number of counted cells }\end{array}$ & & 400 & \\
$\quad \mathrm{X}^{\mathrm{a}}$ & $18 \pm 4$ & $62 \pm 5$ & $\begin{array}{l}\chi^{2}=161 \\
\mathrm{p}\end{array}$ \\
$\begin{array}{l}5-\mathrm{h} \text { phagocytosis } \\
\text { Number of counted cells }\end{array}$ & 400 & 400 & $10^{-10}$ \\
$\mathrm{X}^{\mathrm{a}}$ & $42 \pm 5$ & $76 \pm 4$ & $\begin{array}{l}\chi^{2}=95 \\
\mathrm{p}=3 \times 10^{-10}\end{array}$ \\
\hline
\end{tabular}

a Percentage of phagocytizing macrophages \pm fiducial interval at $p=0.05$

formation by alveolar macrophages). Cadmium also inhibits the ATP-generating system of mitochondria and plasma membranes (14). The biochemical toxic mechanism of this heavy metal remains unclear, but it can act either in competition with other cations, such as zinc (3), or bind the functional dithiol groups (14).

Our results on the cytotoxic effect of cadmium microparticles on rabbit alveolar macrophages are compatible with those observed with $\mathrm{Cd}^{++}(9,14,21)$, i.e., a decrease in phagocytic ability, in the aptitude to kill phagocytized microorganisms, and in the dissolved oxygen consumption and an increase in macrophage death rates. According to Mustafa et al. (14) cadmium oxide with a slightly alkaline $\mathrm{pH}$ may form a hydrate, and then a hydroxide which conducts to cadmium ions.

Important differences were observed between the results obtained in vitro and in vivo with cadmium and lead micro- particles. In vitro, cadmium was twice as toxic as lead, though more slowly, for the alveolar macrophages (7), while in vivo inhaled cadmium microparticles (4) were five times as toxic as inhaled lead microparticles (3). Besides, the pulmonary clearance of inhaled cadmium is much slower (1) than for inhaled lead (2). The assumption that these contradictions can be partially explained by a lower ability of the alveolar macrophages to phagocytize cadmium particles has been verified.

Another phenomenon can modify the toxicity of cadmium for macrophages at low levels of exposure; using soluble cadmium, Waters et al. (22) observed the synthesis of a low molecular weight substance capable of binding cadmium by rabbit alveolar macrophages in vitro. Last, to evaluate the relevance of the concentrations used in our in vitro experiments for the in vivo situation, one can 
compare the threshold dose of microparticulate cadmium in vitro to cadmium amounts of $3 \mu \mathrm{g}$ per gram of lung in vivo.

\section{ACKNOWLEDGMENTS}

We wish to thank F. Girard, H. Peronny, M. Barral and P. Schuman for their helpful collaboration.

This work was supported by a grant from the French Ministère de l' Environnement et du Cadre de Vie.

\section{REFERENCES}

1. BOISSET, M., GIRARD, F., GODIN, J. and BOUDENE, C. Cadmium content of lung, liver and kidney in rats exposed to cadmium oxide fumes. Int. arch. occup. environ. health 41 (1978) 41-53.

2. BOUDENE, C., MALET, F. and MASSE, R. Fate of $210 \mathrm{~Pb}$ inhaled by rats. Toxicol. appl. pharmacol. 41 (1977) 271-276.

3. BOULEY, G., DUBREUIL, A., ARSAC, F. and BOUDENE, C. Effect du plomb microparticulaire, introduit dans l'appareil respiratoire, sur la sensibilité de la souris à l'infection par aérosol de Pasteurella multocida. C. r. acad. sci. paris 285 (1977) $1553-1556$.

4. BOULEY, G., DUBREUIL, A., DESPAUX, N. and BOUDENE, C. Effects of cadmium microparticles on the respiratory system: An experimental study on rats and mice. Scand. j. work environ. \& health 3 (1977) $116-121$.

5. BRIAT, M. Evaluation of levels of $\mathrm{Pb}, \mathrm{V}$, $\mathrm{Cd}, \mathrm{Zn}$ and $\mathrm{Cu}$ in the snow of Mt Blanc, during the last 25 years. In: M. M. BENARIE (ed.), Atmospheric pollution 1978. Elsevier, Amsterdam, Oxford, New York 1978, pp. 225-228.

6. DIAMOND, E. M. and KENCH, J. E. Effects of cadmium on the respiration of rat liver mitochondria. Environ. physiol. biochem. 4/6 (1974) 280-283.

7. DUBREUIL, A., BOULEY, G., GODIN, J., ARSAC, F. and BOUDENE, C. Mesure de la toxicité du plomb émis par les véhicules automobiles sur les macrophages alvéolaires de lapin, in vitro. In: Atti del $1^{\circ}$ convegno internazionale sull'ambiente, Torino May 4-12, 1974 (communication 413).

8. FRIBERG, L., PISCATOR, M. and NORDBERG, G. (eds.). Cadmium in the environment. CRC Press, Cleveland, OH 1971. $166 \mathrm{p}$.
9. GRAHAM, J. A., GARDNER, D. E., WATERS, M. D. and COFFIN, D. L. Effect of trace metals on phagocytosis by alveolar macrophages in vitro. Infect. immun. 11 (1975) 1278-1283.

10. HADLEY, J. G., GARDNER, D. E., COFFIN, D. L. and MENZEL, D. B. Inhibition of antibody-mediated rosette formation by alveolar macrophages: A sensitive assay for metal toxicity. J. reticuloendothel. soc. 22 (1977) $417-425$.

11. HIDALGO, H. A., KOPPA, V. and BRYAN, S. E. Cadmium binding in nuclei: Effect on RNA polymerase in rat liver, following metal challenge. Fed. proc. 35 (1976) 1415.

12. LE FEVRE, M. E. Problems in the measurement of tissue respiration with the oxygen electrode. Bio Science. 20 (1970) $761-764$.

13. LELLOUCH, J. and LAZAR, P. (eds.). Methodes statistiques en expérimentation biologique. Flammarion, Paris 1974. 283 p.

14. MUSTAFA, M. G., CROSS, C. E. and TYLER, W. S. Interference of cadmium ion with oxidative metabolism of alveolar macrophages. Arch. intern. med. 127 (1971) $1050-1058$.

15. MYRVIK, Q. N., LEAKE, E. S. and FARISS, B. Studies on pulmonary alveolar macrophages from the normal rabbit: A technique to procure them in a high state of purity. J. immunol. 86 (1961) 128-132.

16. PELLETIER, M. and DELAUNAY, A. Effet éxercé in vitro par une fraction $d^{\prime}$ histones sur la mort intracellulaire, après phagocytose de différents germes. Ann. inst. pasteur paris 111 (1966) 413-426.

17. PHILLIPS, H. J. Dye exclusion tests for cell viability. In: $P$. F. KRUSE and $M$. $K$. PATTERSON (eds.), Tissue culture: Methods and applications. Acad. Press, New York, San Francisco and London 1973, pp. $406-408$.

18. SILVERBER, B. A. Cadmium induced ultrastructural changes in mitochondria of freshwater green algae. Phycologia 15 (1976) 155-159.

19. SINA, J. F. and CHIN, B. Cadmium modification of nucleolar ultrastructure and RNA synthesis in Physarum polycephalum. Toxicol. appl. pharmacol. 43 (1976) 449459.

20. ULRICH, F. Effect of trypsin on protein synthesis in macrophages. Exp. cell res. 101 (1976) 267-277.

21. WATERS, IM. D., GARDNER, D. E., ARANYI, C. and COFFIN, D. L. Metal toxicity for rabbit alveolar macrophages in vitro. Environ. res. 9 (1975) 32-47.

22. WATERS, M. D., NORDBERG, G. F., COX, C. C., VAUGHAN, T. W. and COFFIN, D. L. Cellular toxic effects of cadmium and other metals. In: International conference on heavy metals in the environment abstracts, Toronto October 2731, 1975, B54-B56. 